\title{
The Effect Of Entrepreneurial Self Efficacy And Entrepreneurial Creativity To Entrepreneurial Intention From Students In Tarumanagara University
}

\author{
Nandinto Martin and Hannes Oey Widjaja \\ S1 Study Program Management Faculty of Economics, The University, Jakarta \\ E-mail: Nandito.wudi90@gmail.com
}

\begin{abstract}
This study aimed to examine how an Entrepreneurial Self-efficacy, and Entrepreneurial Creativityaffect Entrepreneurial Intention. The sample in this study were 100 students in Tarumanagara University.. The sampling technique used is purposive sampling. Data collection technique used is questionnaire. The findings show that Entrepreneurial Self-efficacy and Entrepreneurial Creativitydid affect Student's Entrepreneurial Intention in Tarumanagara Univesity .
\end{abstract}

Keywords: Self Efficacy, Entrepreneurial Creativity, Entrepreneurial Intention

\section{BACKGROUND}

The dynamics of the economy in Indonesia can not be separated from the role of entrepreneurs. Economic growth will affect various aspects of life of Indonesian society ranging from the price of basic necessities, education, security, employment and so forth. High unemployment shows the narrowness of jobs. Indonesian society today complained about the narrowness of employment and self-employment is a solution that can be used as a way out.

According to Rumawouv (2010), the presence of entrepreneurship can help a country's economic growth and to maximize the potential of entrepreneurship will strengthen entrepreneurial economy because in the process of creating added value and development in various aspects. Emergence and development of entrepreneurship will also develop jobs for the community.But one of the vocational school is being developed by UGM (Gadjah Mada University) has a slogan with a goal scored graduates ready to work. The phrase "work-ready graduates" such as these suggest that schools only educate someone to be an employee. The number of employees is increasing while the number of jobs have been added, so that the unemployment rate is increasing.

Developing an interest in entrepreneurship is felt not maximized looks like there is still a view to what high school if just want to be a trader (Alma, 2011).According Ramayah and Aaron (2005), the intention of entrepreneurship is defined as the tendency of the individual's desire to perform the action of entrepreneurs by creating new products through business opportunities and taking risks. Entrepreneurial activity is largely determined by the individual's own intentions. People are not going to be an entrepreneur suddenly without any specific triggers

Before an entrepreneur become business owners, entrepreneurs need to have an interest in entrepreneurship. According Wulandari (2013) interest in entrepreneurship is the desire, interest, and willingness to work hard or willed to strive to the maximum in 
meeting their needs without being afraid to risk it, and willed to learn from the failure of his efforts.A person with an interest in a high plane will demonstrate high achievement in the field. When interest is already there then someone will try to find a solution to the matter at hand (Arita, 2008).

The importance of entrepreneurship for students needs to be shown early or early on so that students graduate from universities in Indonesia not only hang himself in the world of work but capable of creating jobs. Central Statistics Agency (2013) recorded the number of unemployed university graduate or graduate in February 2013 reached 360 thousand, or $4.04 \%$ of total unemployment reached 7.17 million people. This new problems arise because college graduates still unemployed and the student's role as a social problem solvers in the community become less effective.

The learning process of students as entrepreneurs directly or indirectly related to selfefficacy. Self-efficacy according Indarti (2008) is a person's belief in the ability of him to complete a task. If someone already has the trust and confidence to complete the task then this person will be willing to take risks as an entrepreneur.

The importance of self-efficacy determine the steps to be taken someone because according Indarti (2008) self-efficacy of career a person can be an important factor in determining whether a person's interest in entrepreneurship has been formed in the early stages of somebody starting his career. Of course in entrepreneurship will be a lot of tasks and work to be done, self-efficacy plays a role in terms of providing confidence in the ability of individuals to complete tasks and work.Lack of self-efficacy on entrepreneurship would create difficulties in connecting entrepreneurs circumtances difficult, with benefits, such as income, appreciation and mental achievement, so it will affect the level of intent in entrepreneurship (Chen et al., 1998).

Once a student has had confidence in themselves (self-efficacy) for the selfemployed, students who will entrepreneurship will certainly face challenges or tasks in diverse and varied work. How the solution will also be very diverse and require creative measures to bring a new innovation.Suryana (2003) states that creativity is: "Think something new". "Creativity as the ability to develop new ideas and to find new ways to solve problems in the face of opportunity".

Creativity is a topic that is relevant not only for entrepreneurs who are just starting out, but also for businesses and business activities in general. Creativity is an important source of competitiveness for the creation of all organizations concerned with the growth (growth) and change (changes).Low or lack of entrepreneurial creativity will make less entrepreneurial ideas and unique that will affect the interest in entrepreneurship.

\section{THEORITICAL REVIEW}

Before an entrepreneur become business owners, entrepreneurs need to have an interest in entrepreneurship. According Wulandari (2013) interest in entrepreneurship is the desire, interest, and willingness to work hard or willed to strive to the maximum in meeting their needs without being afraid to risk it, and willed to learn from the failure of his efforts.A person with an interest in a high plane will demonstrate high achievement in the field. When interest is already there then someone will try to find a solution to the matter at hand (Arita, 2008).

Self efficacy is a person's belief in the ability of him to complete a job, task, achieving goals and overcoming obstacles in a variety of situations (Bandura, 1986). 
Self-efficacy can also be a person's self confidence to tries something new and difficult, and overcoming hkesulitan that arise in certain situations (Cross et al, 2006; Luszczynska et al, 2005; Scholz et al, 2002).

According to Hasan (2013) creativity has a correlation with interest in entrepreneurship. Alma (2011) also said that the primary capital's entrepreneurs are creativity, tenacity and unyielding spirit. Creative entrepreneur who has always had a different way from most people that a creative entrepreneur can change challenges into an opportunity.

According to Guilford (in Munandar, 2011) that people have many more creative ways in which the divergent thinking using many alternative answers in solving the problem. Of course, this capability will help a person to become an entrepreneur reliable.

According Wulandari (2013) interest in entrepreneurship is the desire, interest, and willingness to work hard or willed to strive to the maximum in meeting their needs without being afraid to risk it, and willed to learn from the failure of his efforts

According to Arita (2008), a person with mina berwirausahat a high plane will demonstrate high achievement in the field. When interest is already there then someone will try to find a solution to the matter at hand.

Figure 1. Framework

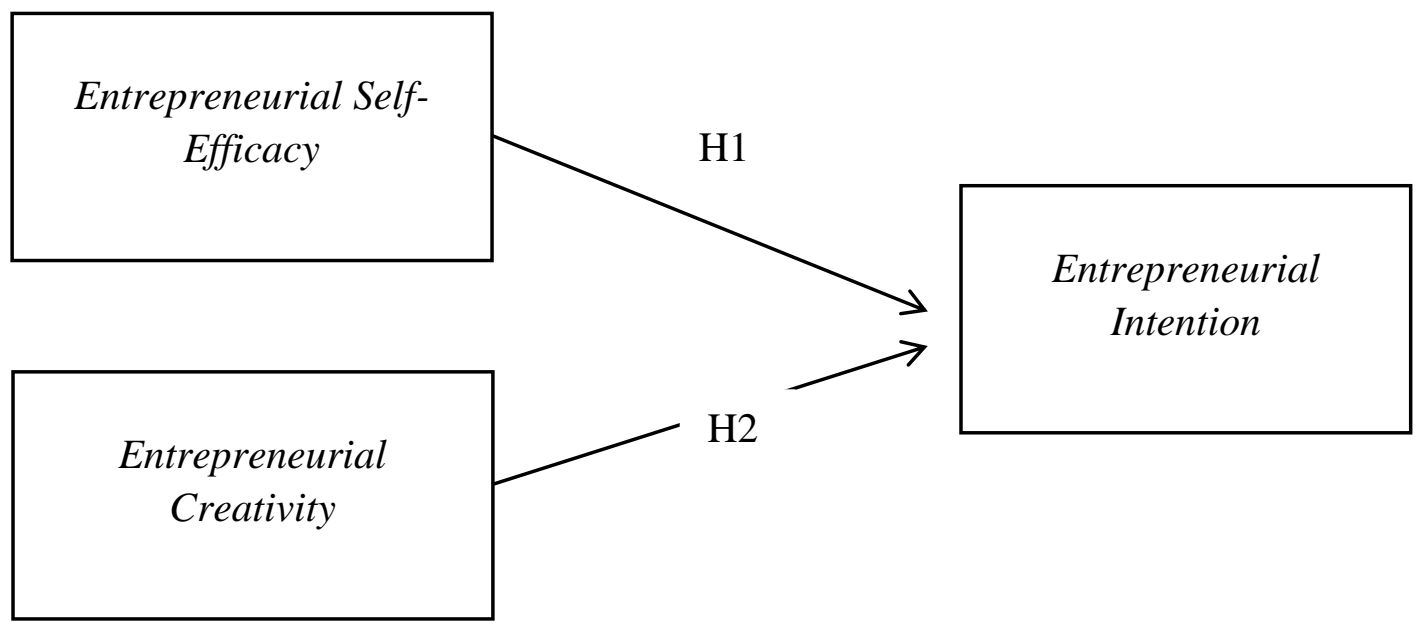

The hypothesis of the model is built on are as follows:

H1: Entrepreneurial Self Efficacy has an influence on interest in entrepreneurship

H2: Entrepreneurial Creativity has an influence on interest in entrepreneurship

\section{METODHOLOGY}

The research design used in this research is descriptive method that aims to create a systematic descriptive, factual, and accurate information on the facts and the properties of the population. Through the application of descriptive methods are expected to researchers get precise and accurate information as well as an overview of correlation of influence 
Entrepreneurial Self-efficacy (X1) and entrepreneurial Creativity (X2) to entrepreneurial Intention (Y).

The study population was a student in Faculty of Economics, University of Tarumanagara with a sample of 100 students in Faculty of Economics, who has been taking courses in entrepreneurship. With the variable's self-efficacy and creative. According to Supranto (2008: 68), he suggests that the population is a collection of all elements of similar but can be distinguished from each other because of different characteristics.

Sampling was conducted at the University Tarumanagara with a sample size of 100 by Roscoe (1982; in Sugiyono, 2011: 90) states that 30 samples is the minimum requirement in one study, while according to another opinion of Roscoe (1982; in Sugiyono, 2011: 90), which states that in studies with multivariate analysis (correlation or multiple regression), the number of members of the sample that can be used is at least 10 times the number of variables studied. The samples used in the study were as much as 3 variables to be studied and multiplied by 10 to get the results of 30 samples to be studied. According to the author of a sample of 100 is already qualified in the study who were in the Faculty of Economics, University of Tarumanagara.

In this study will use the scale interval where students were asked to respond with a choice of a number between 1-5. Perceptions of respondents measured using ordinal scale. Malhotra (2010: 308) argues that the scale Ordinal is a measurement scale with five response categories ranging from "strongly disagree" to "strongly agree" that requires the respondent to indicate the level of agreement or disagreement with each series of statements relating to the object of the stimulus. Measurement of respondents graded on a scale Ordinal are sorted by weight: $1=$ Strongly Disagree (STS), $2=$ Disagree (TS), $3=$ Neutral (N), 4 = Agree (S), 5 = Strongly Agree (SS )

\section{STATISTICAL TEST RESULTS}

Testing the validity of the data in this study was measured using loading factor values, convergent validity, and discriminant validity. Rated loading factor must be greater than 0.5. To measure the value of convergent validity can be measured by the value of Average Variance Extracted (AVE) that must be greater than 0.5 and the loading factor values above 0.6.value loading factors in this study have a value above 0.5. With the highest value in the indicator value intension of entrepreneurship by 0911 and the lowest value contained in the Self-efficacy indicator that is worth 0615. It can be concluded that all the indicators used in this study has been qualified.

Testing the Reliability of dataThis study using Cronbach's alpha and composite reliability in order to test the reliability. The data can be declared reliable if the results of Cronbach's alpha values> 0.6 and also has a value of composite reliability $(\mathrm{CR})$ is greater than or equal to 0.6. Here is the result of the value of Cronbach's alpha and composite reliability. Cronbach's alpha on Self-efficacy has a value of 0.895 , Creativity has a value of 0,929, and Intemsi entrepreneurship has a value of 0,906.dan Composite reliability Selfefficacy has a value of 0.921, 0.942 and Intention entrepreneurship Creativity 0928.

$\mathrm{R} 2$ is used to assess the influence of variation between the independent variable on the dependent variable (Ghozali, 2014). If the R-square value above 0.75 then had a strong influence, while 0,5 - has influence were 0.74 and 0.25 to 0.49 has a weak influence. The magnitude of the effect of $\mathrm{X} 1$ and $\mathrm{X} 2$, on $\mathrm{Y}$ in this study was $76.6 \%$, and also can be said 
the coefficient of determination (R2) has influencestrong. While Intention entrepreneurship $23.4 \%$ influenced by other variables that are not included in this study.

Testing the path coefficients have a value which self efficacy variable influence on entrepreneurship intentions of entrepreneurship that is equal to 0:00, Creativity variables have an influence on entrepreneurship intention is equal to 0.00 .

Testing Goodness of Fit (GoF) To be able to perform compatibility testing models in this study, the value of GoF (Goodness of Fit) can be calculated manually by entering a value AVE and the coefficient of determination. The following is a calculation of the value of Goodness of Fit (GoF):

$$
\begin{aligned}
& \overline{A V E}=0,672 \\
& \overline{R^{2}}=0,475 \\
& \text { GoF }=\sqrt{A V E x R^{2}} \\
& \text { GoF }=\sqrt{ } 0.672 \chi 0475 \\
& \text { GoF }=0564
\end{aligned}
$$

Hypothesis testing which has been carried out in this study to determine whether the hypotheses that have been made in this study have significant influence. The research hypothesis testing seen from the t-statistics or p-values.

It can be seen that the t-statistic must have a value> 1.96 and p-values below 0.05 $(5 \%)$. Therefore we can conclude that the independent variable (X), namely Self-efficacy and creativity has a significant influence on the dependent variable (Y) is the intension of entrepreneurship.

Based on the results of testing that has been done on Self Efficacy variables (X1) to the intention of entrepreneurship (Y) has a T-statistic value that is equal to 3,845 and $\mathrm{P}$ valuesnya that of 0000 , the $\mathrm{H} 10$ is rejected because the known value of the T-statistic greater than 1.96 and $\mathrm{P}$ valuesnya more than 0.05 , from the above explanation, it can be explained and concluded that the Self Efficacy has an influence on the intension of entrepreneurship at the University of Tarumanagara.

Based on the results of testing that has been done on Creativity variable (X2) to the intention of entrepreneurship (Y) has a T-statistic value that is equal to 3,932 and $\mathrm{P}$ valuesnya that of 0000 , the $\mathrm{H} 10$ is rejected because the known value of the T-statistic greater than 1.96 and $\mathrm{P}$ valuesnya more than 0.05 , from the above explanation, it can be explained and concluded that creativity has an influence on the intension of entrepreneurship at the University of Tarumanagara.

Explanation test the hypothesis above, it can be said that the variables of selfefficacy and creativity have a significant effect on entrepreneurial intentions.

\section{DISCUSSION}

The results from entrepreneur's self efficacy affect entrepreneurial's intention in Tarumanagara University shows that T-statistic is equal to 3,845 and 0.000 P-values, which means H1o was rejected. And may imply that self-efficacy variables have an influence on entrepreneurship at the University Tarumanagara intentions. In accordance with the theory diuangkapkan by Indarti (2008)self-efficacy is an important factor in influencing the entrepreneurial intentions. 
The higher entrepreneur'sself-efficacy will help a person to make decisions, which is directed toward thinking, strong self-confidence, and ready to face all the risks that exist. The importance of self-efficacy determine the steps to be taken someone because according Indarti (2008) self-efficacy of career a person can be an important factor in determining whether a person's interest in entrepreneurship has been formed in the early stages of somebody starting his career.

From the discussion above Self-efficacy has an influence on entrepreneurship at the University Tarumanagara intentions. The higher Self-efficacy will help a person to make decisions, which is directed toward thinking, self-confidence is strong and ready to face all the risks that exist.

The results from entrepreneurial creativity affect entrepreneurial's intention in Tarumanagara University showsown T-statistic that is equal to 3,932 and $0.000 \mathrm{P}$-values, which means was $\mathrm{H} 2 \mathrm{o}$ rejected. And may imply that entrepreneurial creativity variables have an influence on entrepreneurship at the University Tarumanagara intentions.

The results of these tests in accordance with the theory of Hasan (2013) and Alma (2011) that an entrepreneur will have a challenging task and a very varied work is very. How the solution is also very diverse and require creative measures to bring a new innovation in their field. According to Hasan (2013) creativity has a correlation with interest in entrepreneurship. Alma (2011) also said that the main capital of an entrepreneur are creativity, perseverance, and unyielding spirit.

From the discussion above it can be concluded that Entrepreneurial Creativity has the effect to the Entrepreneurial Intention at the University of Tarumanagara. Creativity is the main capital for an entrepreneur as well as, tenacity and unyielding spirit that should be owned by every entrepreneur.

\section{CLOSING}

Related to the research that has been done, there are some suggestions that are expected to be useful, following suggestions from researchers: 1) The variables examined in this study only two independent variables, self-efficacy and creativity is also a dependent variable is the intention of entrepreneurship. While there are still many unknown factors or other variables that can influence the entrepreneurial intentions. 2) Due to the limited time and funds, the research conducted involves only a sample of 100 respondents in the University Tarumanagara. 


\section{REFERENCES}

Albert. (2018). Entrepreneurial education, self-efficacy and intentionsin Sub-Saharan Africa. African Journal of Economic and Management Studies.

Arita, LR (2007). Marketing Research. First Edition. Bogor: Ghalia Indonesia.

Brown, J. Broderick, A., \& Lee, N. (2007). Word of mouth communication in online communities: conceptualising the online social network. Journal of Interactive Marketing, Vol. 21 No. 3, pp. 2-20.

Chin, WW (1988). the partial least squares approach for structural equation modeling. In GA Marcoulides (Ed.), Modern methods for business research. 295-236. London: Lawrence Erlbaum Associates.

Cohen, J. (1988). statistical power for the behavioral sciences analysist 2nd edition. Hillsdale NJ: Erlbaum Associates.

Covin, J. (1991). Entrepreneurial firms versus conservative: a comparison of strategies and performance. Journal of Management Studies Vol. 28 No. 5, 439-61.

Eisenhardt, K. (2000). Dynamic capabilities: what are they? Strategic Management Journal, Vol. 21, 1105-1121.

Eric. (2011). The impact of entrepreneurial role models bound story on self-efficacy and entrepreneurial intention. International Journal of Entrepreneurial Behavior \& Research.

Ernami. (2011). Creativity and Innovation Against Influential Small Business Entrepreneurship. JOURNAL OF MANAGEMENT AND ENTREPRENEURSHIP, Vol.13, NO. 1.

Fitts, HW (1971). The Self Concepy and Self Actualization, Los Angeles, California.

Ghozali, I. (2005). Applications Multivariate Analysis with SPSS. Semarang: Diponegoro Publisher Agency.

Ghozali, I. (2014). Structural Equation Modeling, Alternative Methods With Partial Least Square (PLS). Issue 4. Semarang: Diponegoro University Publishers Agency.

Hajli, H. (2014). "A study of the impact of social media on consumers", International Journal of Market Research. Vol. 56 No. 3, pp. 387-404.

Jarna, Ulla, and Pekka. (2011). The role of creativity in search of opportunity and business idea creation. Education + Training, Vol. 53 No. 8/9.

Lanang, IG, and Ni, MP (2016). EFFECT OF ENTREPRENEURSHIP EDUCATION, SELF EFFICACY AND LOCUS OF CONTROL ON THE INTENTION entrepreneurship. E-Journal of Management Udayana University, Vol. 5, No. 2, 2016: 1160-1188.

Malhotra, N. (2004). Marketing Research: An Applied Orienation. New Jersey: Pearson Education Inc.

Malhotra, NK (2009). Marketing Research: An Applied Orientation (6th ed.). (S. Yagan, ED.). New Jersey: Pearson.

Mason, SI (1998). The Entrepreneur. New England Journal of Entrepreneurship, 6.

Pamungkas. (2014). EFFECT OF SELF EFFICACY, ENTREPRENEURSHIP EDUCATION AND INCOME EXPECTATIONS OF STUDENTS entrepreneurship interest ACCOUNTING STUDIES PROGRAM FACULTY OF ECONOMICS YOGYAKARTA STATE UNIVERSITY. 
Purwanti. (2012). EFFECT OF ENTREPRENEURIAL CHARACTERISTICS, CAPITAL BUSINESS, MARKETING STRATEGIES ON DEVELOPMENT OF SMES IN THE VILLAGE AND KALILONDO SALATIGA contracting out tasks.

Purwanti, E. (2012). Characteristics Influence Entrepreneurship, Venture Capital, Marketing Strategy Development Of SMEs In the village of contracting out tasks and Kalilondo Salatiga. Among Makarti, Vol.5 9 ,.

Rifqi. (2015). RELATIONSHIP BETWEEN SELF EFFICACY AND CREATIVITY WITH interest in entrepreneurship. Journal of Theory and Applied Psychology, Vol. 5, No. 2, 81-90.

Have now, U., \& Bougie, R. (2013). Research Methods for Business. United Kingdom: John Wiley \& amp; Sons Ltd.

Sternberg, RJ (2001). The Predictive Value of IQ.

$\mathrm{Su}, \mathrm{Z}$., \& Xie, E. a. (2011). Entrepreneurial orientation and firm performance in new ventures and established firms. Journal of Small Business Management, Vol. 49 No. 4, ,

Sugiyono. (2005). Business Research Methods. Bandung: Alfabeta.

Sugiyono. (2006). Educational Research Methods (Quantitative Approach, Qualitative and R \& D). Bandung: Alfabeta.

Sugiyono. (2007). Statistics For Research. Bandung: Alfabeta.

Sugiyono. (2012). Education peneitian method (Quantitative Approach, Qualitative and R \& D), Bandung: Alfabeta.

Supranto, J. (2012). Research Methods, Applications in marketing. Jakarta: PT Asdi Mahasatya.

Tenenhaus, M., Vinci, Chatelin, YM, and Carlo, L. (2004). PLS Path Modeling. Computtional Statistics and Data Analysis. , 48: 159-205.

Turker, D. (2009). Which Affect factors of entrepreneurial intention of university students? Journal of European Industrial Training, Vol. 33 No. 2.

Wales, WG (2013). Empirical research on entrepreneurial. International Small Business Journal, Vol. 31 No. 4, pp. 357-383.

Yasir. (2018). Entrepreneurial self-efficacy and intention: do entrepreneurial creativity and education matter? International Journal of Entrepreneurial Behavior \& Research. 